\section{The international subarachnoid aneurysm trial (ISAT)}

The Radcliffe Infirmary, Oxford Richard SC Kerr, Andrew J Molyneux, Julia A Shrimpton, the ISAT Collaborative Group

Introduction : This paper will describe the international subarachnoid aneurysm trial (ISAT), its protocol, methods, objectives and early results.

Methods : To compare the safety and efficacy of an endovascular treatment policy of ruptured intracranial aneurysms with a conventional neurosurgical treatment policy in an eligible population.

Primary Objective : To determine whether an endovascular treatment policy of acutely ruptured intracranial aneurysms compared with a neurosurgical treatment policy reduces the proportion of patients with a moderate or poor outcome (defined by Rankin grade $3-6$ ) by $25 \%$ at one year.

\section{Secondary Objectives :}

To determine whether endovascular treatment :

- Is as effective as neurosurgery in preventing re-bleeding from the treated aneurysm

- Results in a better quality of life than neurosurgery at one year (Euroqol measure)

- Is more cost effective than neurosurgical treatment

- Improves the neuropsychological outcome at one year (UK centres)

Tertiary Objectives : To examine the longer term outcome over five years with specific reference to re-bleed rates and determine the long term significance of angiographic results.

Results : 44 centres in Europe, North America and Australia have entering a total of 2,143 patients into the study. ISAT ceased randomisation on 2 May 2002 after a recommendation from the Data Monitoring and Ethics Committee and reported the first results in The Lancet in October 2002.

Conclusion : This study is the largest ever randomised trial of the management of aneurysmal subarachnoid haemorrhage. The results of ISAT are likely to have a significant impact on the management of subarachnoid haemorrhage.

\section{2. 新しい脳動脈瘤治療用コイル：マトリックス}

Division of Interventional Neuroradiology, UCLA School of Medicine 村山 雄一

ISAT StudyによりGDCを用いた脳動脈溜に対する血管内 治療法は，開頭手術に勝る短期的な治療效果が示された。し かしながらGDCの問題点である再開通の危険性は克服すべ き問題点である，GDCの欠点を克服するため，われわれは 再生医療の分野で重要な役割を果たしている生分解性ポリ マーを脳動脈瘤治療に応用した。マトリックスはプラチナと 生分解性ポリマーより構成され, 生体内での分解反忘に伴い, 瘤の創傷治癒機転を促進する。現在欧米 12 施設で臨床応用 され，当施設では30例の症例に対し塞栓術を施行した。初 期治療経験ではGDC と比較するとコイルの摩擦抵抗がやや 高く, loose packingに終わる症例を経験した。それにもかか わらず3カ月のフォローアップでは，従来の GDCでは再開 通が危惧された症例でも完全閉塞が得られ，デバイスとして のパフォーマンスの違いが明らかになった。代表症例を呈示 し，今後の展望について報告する. 